Public Attitudes toward Water Management and Drought in the United States

\author{
James W Stoutenborough, Ph.D. \\ University of Alabama in Huntsville \\ Huntsville, Alabama UNITED STATES \\ Arnold Vedlitz, Ph.D. \\ Texas A\&M University \\ College Station, Texas UNITED STATES
}




\title{
Public Attitudes toward Water Management and Drought in the United States
}

\begin{abstract}
Water management is becoming increasingly salient as climate change continues to alter the environment, resulting in more severe and frequent droughts. To address water management issues, large-scale projects may be needed. However, public support is often a prerequisite for governments at all levels to enact such projects. Given the growing importance of these issues, there are few recent studies that explore public attitudes, preferences, and risk assessments about water-related resource allocations. Will the public act to constrain the actions of their elected officials? Is the public ready to begin considering policies, regulations, and expenditures that address the potential impacts of increased drought frequency on local, state and national water resources? This research reports the results of two national public opinion surveys in the United States that focused on water management and drought issues. The results indicate that the public is willing to support government efforts to manage water, but not if they negatively affect the environment or agriculture.
\end{abstract}

Keywords: drought issues, water management, public attitudes, policy preferences 


\section{Introduction}

As climate change continues, humans will need to adapt to their ever-changing environment. In addition to eventualities like rising sea levels and more extreme weather events, scientists expect that many parts of the world are more likely to experience longer, more intense droughts (e.g. Intergovernmental Panel on Climate Change 2007). These droughts have the potential to alter radically the way of life for those living in affected regions.

Governments, whether they want to or not, will eventually need to become more involved in water management activities. However, in democratic countries like the United States, public support is often a necessary ingredient for political action. Studies consistently find that policymaker actions reflect public preferences (e.g. Burstein 2010). In short, if the public is not on board, it is very difficult for elected officials to find the will to act even if they know it is in the best interest of their country, state, or town.

Understanding public sentiments toward an issue is a necessary step toward legislating on that issue. Given the importance of issues like water management and drought, there is a surprising scarcity of studies that explore public attitudes toward these issues. ${ }^{1}$ Will the public act to constrain the actions of their elected officials? Is the public ready to begin considering policies, regulations, and expenditures that address the potential impacts of droughts on their water supply?

In the United States, responsibilities for managing and protecting water assets are split between several layers of government. State and local governments have a primary responsibility

\footnotetext{
${ }^{1}$ Since 2000, studies of public attitudes toward water-related issues have focused primarily on a single issue - most frequently water reuse (e.g. Dolnicar and Schäfer 2009; Marks et al. 2006; Menegaki et al. 2007) - or a relatively narrow community (e.g. Hurd et al. 2006; Willis et al. 2011). Other studies focus on water quality (e.g. Clay et al. 2007), and not on water management or drought. Finally, many of these studies rely upon a relatively small number of respondents (e.g. Menegaki et al. 2007; Willis et al. 2011).
} 
for water delivery and waste water removal. They also participate in the building of reservoirs and in the management of some flooding and coastal inundation. The federal government shares in the delivery of water and the building of dams and reservoirs on public lands and in the management of water assets that may cut across state boundaries as well as having a key role in forest fire prevention, fighting, and recovery. Through its U.S. Army Corps of Engineers, the national government also plays a major role in construction and maintenance of major dams, levees, and other flood control infrastructures. In addition, the national government is a major insurer of personal and agricultural damage caused by floods and droughts. So, since all levels of government have important roles in water management and damage recovery, views of citizens at the national, regional, and state scales have much to tell us about acceptable policy solutions and resource allocations for water management activities.

This paper reports the results of two large national public opinion surveys that focused on water management and drought issues. This project proceeds in three parts. First, the survey is described. Second, the results of the survey are presented by focusing on public attitudes toward several water management and drought issues. Third, the implications of this project are discussed

\section{Research Methods}

Two national public opinion surveys of adults in the United States were conducted. The first survey was in the field 21 February 2013 to 12 March 2013 and resulted in 1,313 completed surveys for a $56 \%$ completion rate. The second survey, which asked identical questions, was in the field from 2 April 2013 through 16 April 2013 and resulted in 1,311 completed surveys for a 55.5\% completion rate. Both surveys were administered on-line by GfK Custom Research, LLC 
(GfK, formerly Knowledge Networks). ${ }^{2}$ The two unique samples were drawn from GfK’s

KnowledgePanel, a probability-based web panel designed to be representative of the United

States for adults age 18 and over. Descriptive statistics for the demographic characteristics of the samples can be found in Appendix A. ${ }^{3}$ The median survey completion time was 27 minutes. As there were no major water-related focusing events between the two surveys, the pooled results are reported to simplify the presentation of the findings.

\section{Comparing Water to other Issue Domains}

Water issues are contextualized from two perspectives. First, respondents were asked to identify their level of concern for a number of different issue domains on a 0 to 10 scale. Unless otherwise noted, the scaling for all of the survey questions is from lowest to highest. Specific question wording can be found in Appendix B. The mean levels of concern for each of the ten issue domains are illustrated in Figure 1. As indicated, three issue domains - jobs and economic growth, government spending/national debt, and health care - weigh most heavily on the public. The data shows that water quality and availability is the fifth most concerning issue, though it is clustered around three other issues. On average, the public rates water issues a 6.80 on this scale. This suggests the public is certainly more concerned than not about water issues and is generally more concerned about water than many of the other issues. On the whole, this indicates that water quality and availability is a fairly important issue for the public.

\section{[Insert Figure 1 about here]}

\footnotetext{
${ }^{2}$ The survey was fielded twice due to a coding issue with one of the battery stems in the initial sampling, which was corrected prior to the second sampling. The minor coding issue on the first sampling does not affect the integrity of the dual survey results reported here as that particular battery stem is not part of this data analysis nor related to any items in this analysis.

${ }^{3}$ An examination of the demographic characteristics of the two samples indicates that both samples are likely representative of the general population, as they reflect levels that are consistent with Census data. For instance, reflective of recent partisan shifts found in other national public opinion polls (e.g. Gallup), the results show that a larger proportion of the respondents identify as Democrat than Republican. Additionally, as is common in survey research, these samples do have a higher proportion of white respondents. However, it is unclear within the literature the extent to which racial differences influence attitudes toward drought and water management.
} 
The second contextualization perspective relates to perceptions of responsibility. Who is responsible for handling a given policy domain? In our federal system, there are realistically only four types of institutions that can handle a major public issue - the federal government, state governments, local governments, and the private sector. On a 0 to 10 scale, respondents were asked to indicate how responsible each institution is for handling four policy domains - public education, homeland security, energy, and water. As presented in Figure 2, the public believes water policy is the responsibility of all levels of government, but assigns state and local governments the highest responsibility. This differs from issues like homeland security and energy where responsibility begins with the federal government and decreases with each lower level of government until it bottoms out in the private sector. Overall, this suggests that attitudes concerning water issues are particularly applicable to state and local governments and their policy making processes.

[Insert Figure 2 about here]

\subsection{General Water Perceptions}

The public's perceptions on water use were examined. Which water uses does the public find to be more important? Using a 0 to 10 scale, respondents were asked about eight water uses. The results are presented in Figure 3. What emerges is a clear gap. The public views drinking, household use, natural environment, and agriculture as the most important uses of water. On the other hand, industrial use, recreation, and landscaping uses are clearly of lower importance. Indeed, municipal landscaping is viewed as the least important use of water and is the only use that is in the lower half of the scale.

[Insert Figure 3 about here] 
Respondents were also asked about their perceptions of water availability and their willingness to conserve water, using a five-point scale. The results of this battery of questions can be found in Table 1 . The results show that the public is generally optimistic about the current and future water needs of their state. The public does not believe that the economy is more important than the environment in water planning. They generally believe that fish and wildlife habitats and the economy are of equal importance when conservation is necessary. Respondents also disagreed with cities diverting water from rural areas even if cities were in need of more water. This suggests that the public would much rather conserve water than risk negatively affecting agriculture.

\section{[Insert Table 1 about here]}

Is the public willing to conserve water, and under what conditions are they willing to do so? Also depicted in Table 1, the public generally recognizes that issues related to water availability affect them personally, which suggests that this is at least somewhat salient to them, which may indicate a greater likelihood of action. Interestingly, on average, the public would rather the government mandate water restrictions than leave it up to them to act responsibly through voluntary measures, even though they generally believe that conservation is not inconvenient. This suggests that they do not trust their fellow citizens to act responsibly. The results also show that when framed in several manners, the public is generally willing to conserve water. Specifically, on average, the public will conserve to lower their water bill, protect the environment, for agricultural uses, and under extreme drought conditions. Conversely, they are almost evenly divided on conserving for industrial uses, with the public barely more likely to conserve than not. 
Finally, to place these in their proper context, respondents were asked to identify what they believe to be the most important water related issue. The results of this question are illustrated in Figure 4. The results show that $20.64 \%$ of the public believes water distribution, or providing enough water, is the most important issue. $34.68 \%$ of respondents indicated that they believe water quantity, or drought, is the most important issue. Finally, $44.69 \%$ feel that water quality/pollution is the most important issue. Clearly, the public is more concerned about water quality than quantity or, not surprisingly, distribution.

[Insert Figure 4 about here]

\subsection{Drought Opinions}

Having placed water attitudes in their proper context, public perceptions on droughts are now considered. Given the likelihood of increased frequency and intensity (e.g. Intergovernmental Panel on Climate Change 2007), droughts are likely to become a greater water management concern.

A necessary step toward gaining public support is to ensure that they are properly informed on the issue. Studies regularly indicate that knowledge is an essential component of the problem solving process (e.g. Hmelo-Silver 2004). Delli Carpini and Keeter (1996) argued that knowledge influences the quality of the public's debate and resulting policy suggestions on a given issue. Ostrom (2007) argued that imperfect information results in the increased likelihood of selecting improper strategies to solve a problem.

This project analyzed how closely public attitudes mirror those outlined by the Intergovernmental Panel on Climate Change (2007). Does the public believe droughts are becoming more common and more severe? Table 2 presents the results of two questions to ascertain these positions. The majority of the public believes that droughts are just as frequent 
and severe as they have always been. However, a substantial minority, $30.86 \%$, do believe droughts are more common, and $23.66 \%$ believe they are more severe.

[Insert Table 2 about here]

Droughts have also been linked to several water related risks. To what extent does the public recognize the likelihood of these risks as a result of drought? Respondents were asked to evaluate the likelihood of eight drought related risks, which can be found in Table 3 . The results show that the public is, on average, largely unsure about the likelihood of three drought related risks - disruption of water supplies, loss of recreational activities, and reduced water quality. The public views the remaining five risks - increased food prices, increased water prices, damage to animal and plant species, increased fires, and increased water user conflicts - on average, as likely. In particular, the public recognizes that when droughts occur, food and water prices increase.

[Insert Table 3 about here]

\subsection{Government Response to Drought}

Ultimately, it is the responsibility of government to prepare and/or respond to drought conditions. As noted, public support is a necessary component for government action. What actions then, will the public support?

The first step toward understanding the public’s preferences for government response is to determine which water user should be the first to conserve when the water supply shrinks. As illustrated in Figure 5, a plurality, $35.81 \%$ of the public, believes that they, themselves, should be the first to reduce water use when faced with a drought. In a close second, $31.84 \%$ of the public feels that industry should be the first to reduce water use. Interestingly, despite viewing municipal landscapes as being the least important use of water (see Figure 3), only $28.27 \%$ of 
the public believes cities should decrease their water usage first. Finally, consistent with several previous question batteries, only $4.08 \%$ of respondents feel that agriculture should be the first to reduce their water use.

[Insert Figure 5 about here]

When faced with a drought, cities are often limited in their range of potential responses unless they have planned well. What actions will the public support in response to a short-term drought? Figure 6 presents the public's favorability toward four potential strategies. The public is generally in favor of limiting the use of water on private and public lawns. This is also consistent with what the data shows in Figure 3. They are also solidly in favor of limiting water use by industry. Even in short-term situations, the public is far less favorable toward diverting water from agriculture to use in a city.

[Insert Figure 6 about here]

It is also important to understand the public’s favorability toward strategies that will prepare cities for future droughts. These results are found in Figure 7. Overall, favorability toward these strategies is much lower than those for short-term responses. The public is generally in favor of all of these strategies except permanently transferring water from agricultural use and increasing water rates. The most popular long-term strategy is reusing treated waste water for landscaping, followed closely by requiring water conservation. The public is much more divided, but still generally supportive, in terms of the other strategies limiting urban sprawl, building dams and reservoirs, and piping water from other regions.

\section{[Insert Figure 7 about here]}

Previously discussed strategies were framed in terms of city drought responses. It is possible respondents were not in favor of cities taking responsibility for these projects. 
Therefore, strategies were framed in terms of policy options not associated with any particular level of government, except for one that is framed with the national government. Will the public support or oppose adopting policies to deal with water issues?

The results of the policy support battery can be found in Table 4. Generally, the public is supportive of all the policy alternatives. The public most strongly supports a policy that would protect some water resources to preserve wildlife and fishery habitats. There is also fairly strong support for policies that require lawn watering using reclaimed/reused water instead of drinking water, that give tax incentives for the installation of water-saving equipment, that conduct campaigns for voluntary water conservation, and that require low water use landscaping. The public is also more supportive than not for building infrastructure to support water demand during droughts, providing tax cuts to companies to reduce their water use, requiring mandatory water conservation, and developing a comprehensive national plan for allocating water across state borders. The public is consistent in its belief that the federal government is less responsible than state or local governments, as the proposal of the national plan is the least supported policy option, and it received the largest rate of "strongly oppose" responses.

[Insert Table 4 about here]

\section{Discussion}

First, perhaps in recognition of the importance of water, the public is generally supportive of government efforts to manage water resources during a drought and to put plans in place to reduce the impact of future droughts. The findings indicate quite a bit of support for government policies and action. In recognition of the results presented in Figure 2, the public likely expects that these actions will be done by state or local governments. 
Second, the results consistently show that the public will support virtually any effort so long as it does not negatively affect agriculture or the environment. As presented in Figure 5, agriculture is the last place the public wants to look for water supply savings. The public recognizes that disruptions in the water supply will likely increase the cost of food and is much more willing to bear the burden of conserving water than to place this burden on agriculture.

A similar pattern is found with views toward the environment. As seen in Figure 3, the public identifies the natural environment as the third most important use of water. In fact, its mean was slightly larger than that for agriculture (8.32 and 8.28 , respectively). The public generally believes that fish and wildlife habitats are just as important as the economy when considering water conservation (Table 1). Individual respondents were also highly likely to agree or strongly agree (74.79 \%) that they would conserve water to protect the environment (Table 1). The results show that the public recognizes that droughts are likely to damage animal and plant species (Table 3). Finally, $73.50 \%$ of the respondents support or strongly support a policy that would protect some water resources to preserve wildlife and fishery habitats (this was also the most supported policy proposal). It appears the public wants to protect the environment from water shortage issues even if that means they are forced to conserve water to do so.

Third, public attitudes toward voluntary or mandatory conservation are inconsistent. The public is generally in favor of the government requiring conservation. However, the public would rather support a policy that conducts a campaign for voluntary conservation than a policy that mandates conservation. Additionally, the public seems more comfortable with a mandate if it comes from their city. ${ }^{4}$

\footnotetext{
${ }^{4}$ Both variables were rescaled to make their scales from 0 to 40 . The long-term city strategy was originally coded from 0 to 10 , so we multiplied each observation by 4 . The un-named policy was originally coded 0 to 4 , so each observation was multiplied by 10 . Using a T-Test, the means of the two measures were compared and the difference
} 
Fourth, the level of support for recycling waste water for irrigation purposes is somewhat surprising. The results show that the public is quite supportive of recycling water and sees this as one of the best ways to limit the impact of future droughts (Figure 7), which is consistent with examinations of acceptance in Australia (e.g. Dolnicar and Schäfer 2009). While the survey questions focused on using the recycled water for irrigation purposes, it is not clear how well the public would support using this water for potable uses, though Marks et al. (2006) found that Australians prefer using recycled water for non-potable purposes.

Finally, it appears that if a city or state government wants/needs to act to preserve its water supply, the public will generally be supportive of their actions. That said, according to the results presented in Table 1, the government will need to explain why a given action is necessary. Certainly, if it is in response to a severe drought, the public will follow. In nondrought conditions, it appears as though the public will support water management projects if they protect the environment or agriculture assets.

\section{Conclusion}

The findings presented here illustrate clearly that citizen attitudes about drought-related concerns are robust and related to their policy choices in this content area. Citizen understanding of scientific findings, their assessments of risk, and their personal and political decisions are an important context within which local, state and national decisions and resource allocations on water issues will be made. Understanding this context is important for decision makers in framing policies, selecting implementation strategies and providing citizen education opportunities. Additionally, this context may shed light on the nature of water conflicts in the 
United States (see Gunasekara et al. 2014) and other water management issues facing the country (e.g. Deitch et al. 2013; Mays 2013).

\section{Appendix A}

[Insert Appendix Table 1 about here]

\section{Appendix B}

[Insert Appendix Table 2 about here]

\section{References}

Burstein P (2010) Public opinion, public policy, and democracy. In: Leicht KT, Jenkins JC (eds) Handbook of politics: State and society in global perspective. Springer, New York

Clay DE, Ren C, Reese C, Waskom R, Bauder J, Mesner N, Paige G, Reddy K, Neibauer M, Mahler R (2007) Linking public attitudes with perceptions of factors impacting water quality and attending learning activities. J Nat Resour \& Life Sci Educ 36(1):36-44

Deitch MJ, Merenlender AM, Feirer S (2013) Cumulative effects of small reservoirs on streamflow in Northern Coastal California catchments. Water Resour Manage 27(15):5101-5118

Delli Carpini MX, Keeter S (1996) What Americans know about politics and why it matters. Yale University Press, New Haven, CT

Dolnicar S, Schäfer AI (2009) Desalinated versus recycled water: Public perceptions and profiles of accepters. J Environ Manag 90(2):888-900

Gunasekara NK, Kazama S, Yamazaki D, Oki T (2014) Water conflict risk due to water resource availability and distribution. Water Resour Manage 28(1):169-184 
Hmelo-Silver CE (2004) Problem-based learning: what and how do students learn?. Educ Psychol Rev 16(3):235-266

Hurd BH, St. Hilaire R, White JM (2006) Residential landscapes, homeowner attitudes, and water-wise choices in New Mexico. HortTechnol 16(2):241-246

Intergovernmental Panel on Climate Change (2007) Climate change 2007: Impacts, adaptation and vulnerability. Contribution of Working Group II to the Fourth Assessment Report of the Intergovernmental Panel on Climate Change, 2007. Cambridge University Press, New York

Marks JS, Martin WC, Zadoroznyj M (2006) Acceptance of water recycling in Australia: national baseline data. Water 33(2):151-157

Mays LW (2013) Groundwater resources sustainability: past, present and future. Water Resour Manage 27(13):4409-4424

Menegaki AN, Hanley N, Tsagarakis KP (2007) The social acceptability and valuation of recycled water in Crete: a study of consumers’ and farmers’ attitudes. Ecol Econ 62(1):718

Ostrom V (2007. The intellectual crisis in American public administration, 3rd edn. University of Alabama Press, Tuscaloosa

Willis RM, Stewart RA, Panuwatwanich K, Williams PR, Hollingsworth AL (2011) Quantifying the influence of environmental and water conservation attitudes on household end use water consumption. J Environ Manag 92(8):1996-2009 
Figure 1: Comparing Public Concern for Water Quality \& Availability Against Other Issue Domains

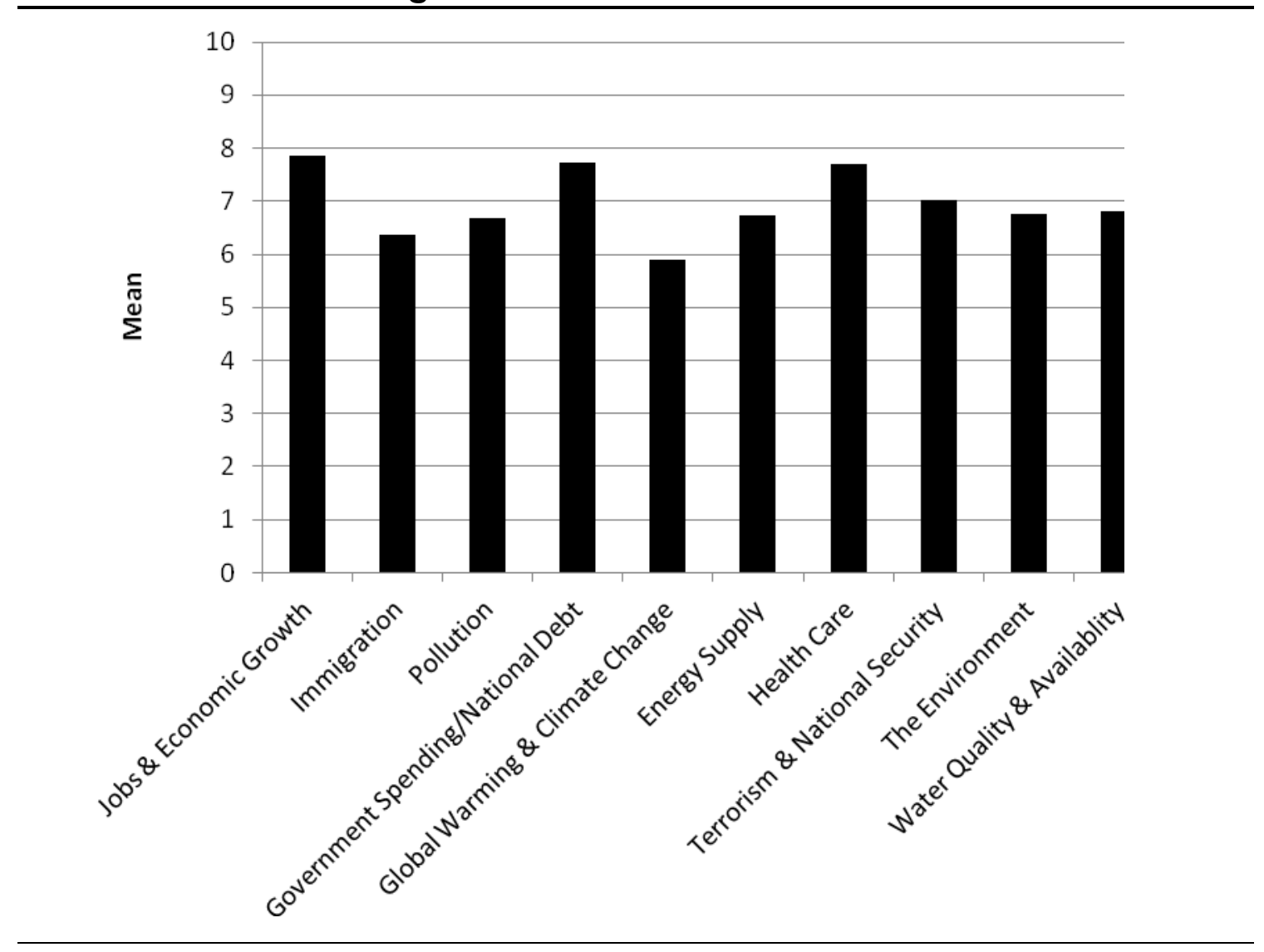


Figure 2: Comparing Perceptions of Responsibility for Water Policy Against Other Policy Domains

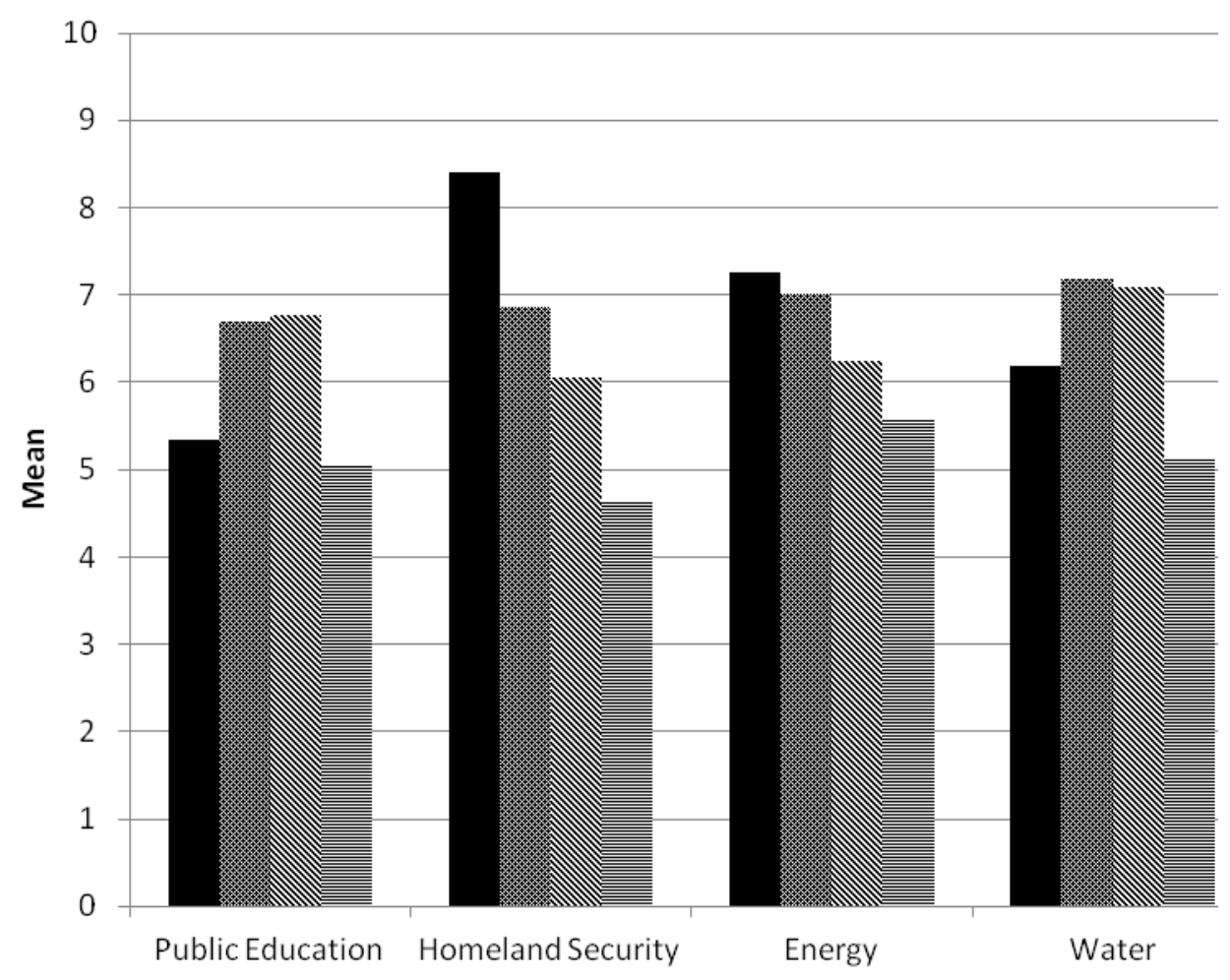

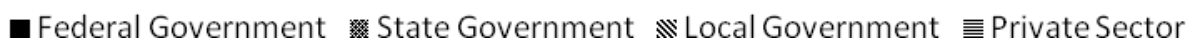


Figure 3: Public Views on the Importance of Various Water Uses

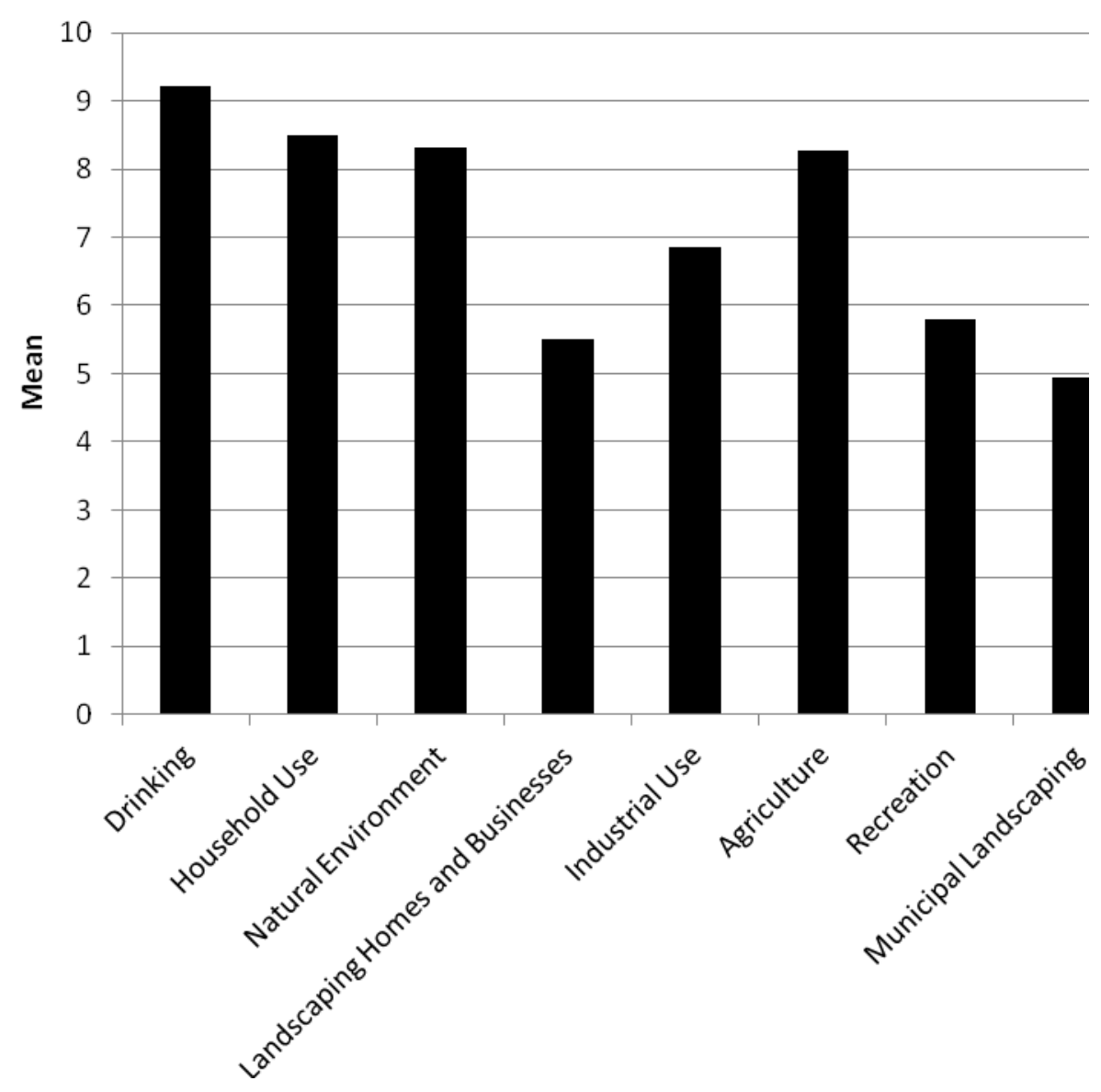


Table 1: Public Perceptions of Water Availability and Willingness to Conserve Water

\begin{tabular}{|c|c|c|c|c|c|c|}
\hline & $\begin{array}{l}\text { Strongly } \\
\text { Disagree }\end{array}$ & Disagree & $\begin{array}{l}\text { Neither } \\
\text { Disagree Nor } \\
\text { Agree }\end{array}$ & Agree & $\begin{array}{l}\text { Strongly } \\
\text { Agree }\end{array}$ & Mean \\
\hline $\begin{array}{l}\text { There is enough water in my state to meet } \\
\text { current needs }\end{array}$ & 4.17 & 13.87 & 25.57 & 44.11 & 12.28 & 2.46 \\
\hline $\begin{array}{l}\text { There is enough water in my state to meet } \\
\text { future needs }\end{array}$ & 6.79 & 17.99 & 35.01 & 31.50 & 8.70 & 2.17 \\
\hline $\begin{array}{l}\text { In water planning, the economy is more } \\
\text { important than the environment }\end{array}$ & 11.16 & 30.91 & 39.70 & 14.39 & 3.85 & 1.68 \\
\hline $\begin{array}{l}\text { Water conservation for fish/wildlife habitat } \\
\text { and economic growth are equally } \\
\text { important }\end{array}$ & 1.98 & 10.08 & 31.60 & 44.63 & 11.71 & 2.54 \\
\hline $\begin{array}{l}\text { Cities should be able to divert water from } \\
\text { rural areas if they need more water }\end{array}$ & 8.41 & 26.41 & 41.72 & 20.41 & 3.04 & 1.83 \\
\hline $\begin{array}{l}\text { The issues related to the conservation and } \\
\text { availability of water do not affect me }\end{array}$ & 26.29 & 37.23 & 26.52 & 7.42 & 2.54 & 1.11 \\
\hline $\begin{array}{l}\text { Household water restrictions should be } \\
\text { voluntary rather than mandated by the } \\
\text { government }\end{array}$ & 8.10 & 28.00 & 34.06 & 21.51 & 8.33 & 1.93 \\
\hline $\begin{array}{l}\text { Making efforts to conserve water is } \\
\text { inconvenient }\end{array}$ & 10.63 & 40.38 & 28.00 & 18.77 & 2.22 & 1.61 \\
\hline $\begin{array}{l}\text { I am willing to conserve water to lower my } \\
\text { water bill }\end{array}$ & .97 & 2.83 & 21.08 & 55.28 & 19.84 & 2.90 \\
\hline $\begin{array}{l}\text { I am willing to conserve water to protect } \\
\text { the environment }\end{array}$ & 1.09 & 3.75 & 20.37 & 54.61 & 20.18 & 2.89 \\
\hline $\begin{array}{l}\text { I am willing to conserve water for industrial } \\
\text { uses }\end{array}$ & 4.60 & 19.72 & 47.31 & 24.28 & 4.09 & 2.03 \\
\hline $\begin{array}{l}\text { I am willing to conserve water for } \\
\text { agricultural uses }\end{array}$ & 1.13 & 4.49 & 28.09 & 53.14 & 13.15 & 2.72 \\
\hline $\begin{array}{l}\text { I am willing to conserve water under } \\
\text { extreme drought conditions }\end{array}$ & .62 & 1.13 & 11.15 & 43.50 & 43.61 & 3.28 \\
\hline
\end{tabular}


Figure 4: The Most Important Water Related Issue

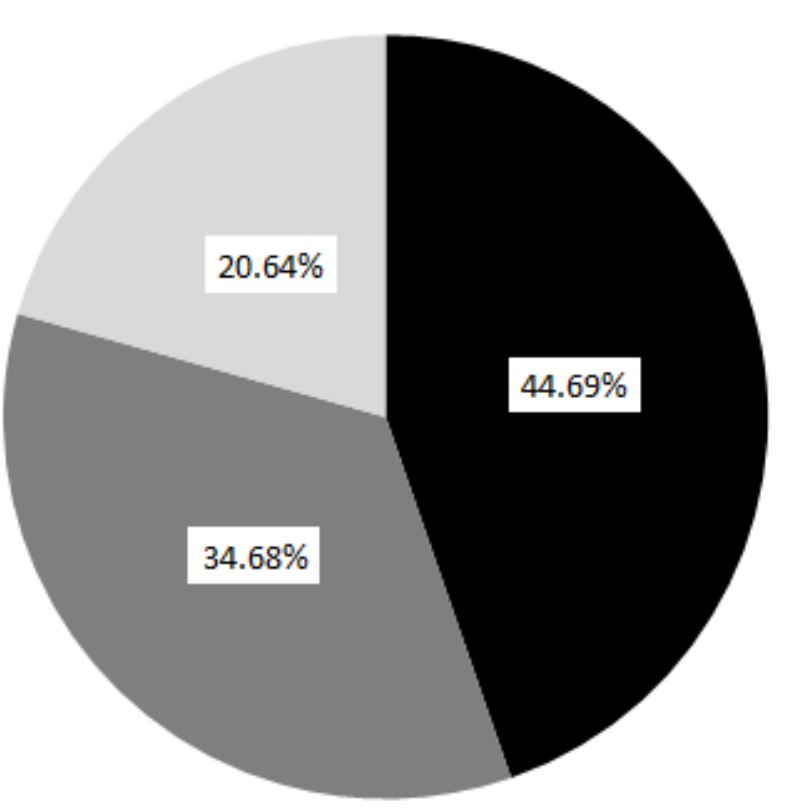

- Water Quality/Pollution

- Water Quantity/Drought

Water Distribution/Provide Enough Water 


\section{Table 2: Public Perceptions on Drought Occurrence and Severity}

\begin{tabular}{llccc} 
& Less & Same & More & Mean \\
\hline $\begin{array}{l}\text { Are droughts in your region becoming more common, less common, } \\
\text { or continuing to occur at the same rate? }\end{array}$ & 7.42 & 61.72 & 30.86 & 1.23 \\
\hline $\begin{array}{l}\text { Are droughts in your region becoming more severe, less severe, or } \\
\text { continuing to occur with the same severity? }\end{array}$ & 8.04 & 68.30 & 23.66 & \multirow{2}{*}{1.15} \\
\hline
\end{tabular}

Values are percentages, except the mean. The mean is calculated using a coding scheme from 0 (Less) to 2 (More). 
Table 3 Public Perceptions of the Likelihood of Drought Risks

\begin{tabular}{|c|c|c|c|c|c|c|}
\hline & Very Unlikely & Somewhat Unlikely & Unsure & Somewhat Likely & Very Likely & Mean \\
\hline Disruption of water supplies & 8.71 & 17.61 & 43.92 & 23.05 & 6.72 & 2.01 \\
\hline Increased food prices & 3.54 & 4.32 & 22.21 & 39.75 & 30.18 & 2.88 \\
\hline Increased water costs & 4.70 & 5.87 & 25.33 & 38.69 & 25.41 & 2.74 \\
\hline Loss of recreational activities & 7.99 & 17.93 & 40.47 & 25.18 & 8.42 & 2.08 \\
\hline Damage to animal and plant species & 5.59 & 11.83 & 38.79 & 30.68 & 13.11 & 2.33 \\
\hline Reduced water quality & 8.63 & 17.07 & 42.69 & 23.72 & 7.89 & 2.05 \\
\hline Increased fires & 5.75 & 11.73 & 34.21 & 30.60 & 17.71 & 2.42 \\
\hline Increased water user conflicts & 6.12 & 9.92 & 39.30 & 30.93 & 13.72 & 2.36 \\
\hline
\end{tabular}


Figure 5: Which Water Use Should Be Reduced First?

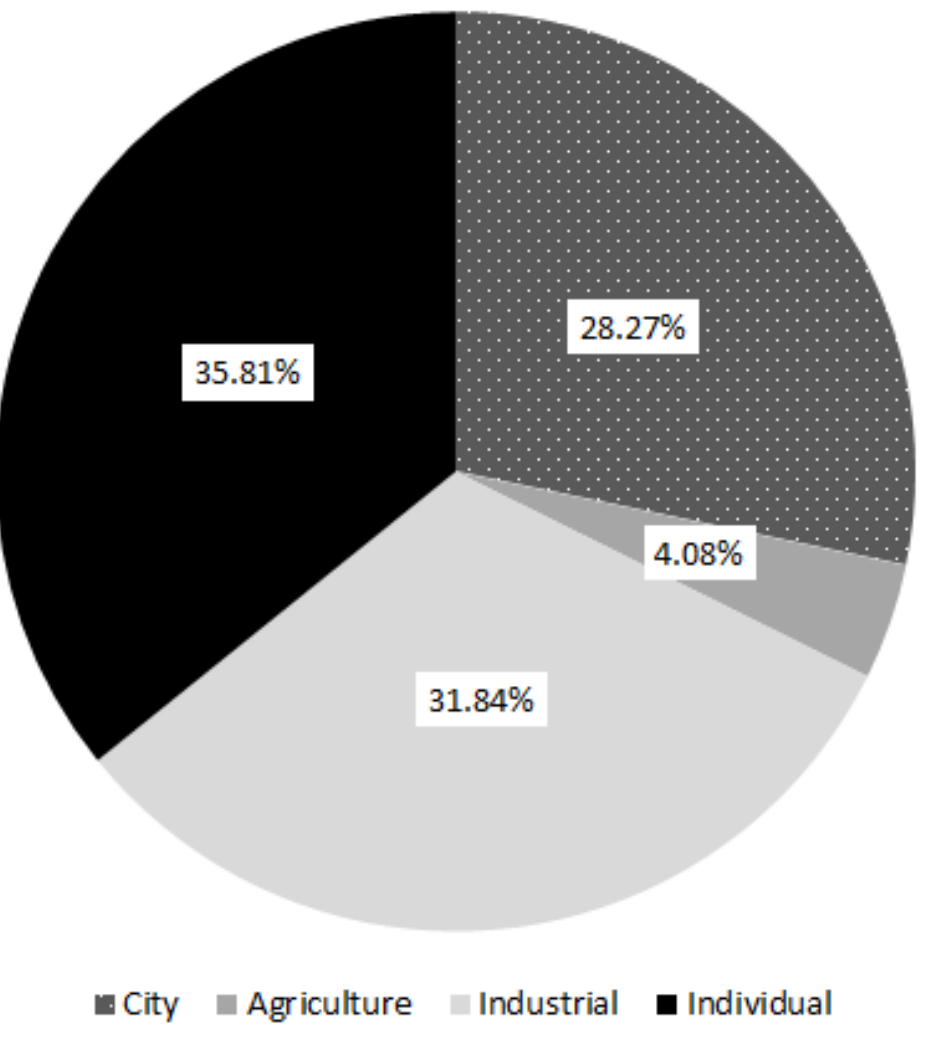


Figure 6: Favorability of Short-Term Drought Strategies by Cities

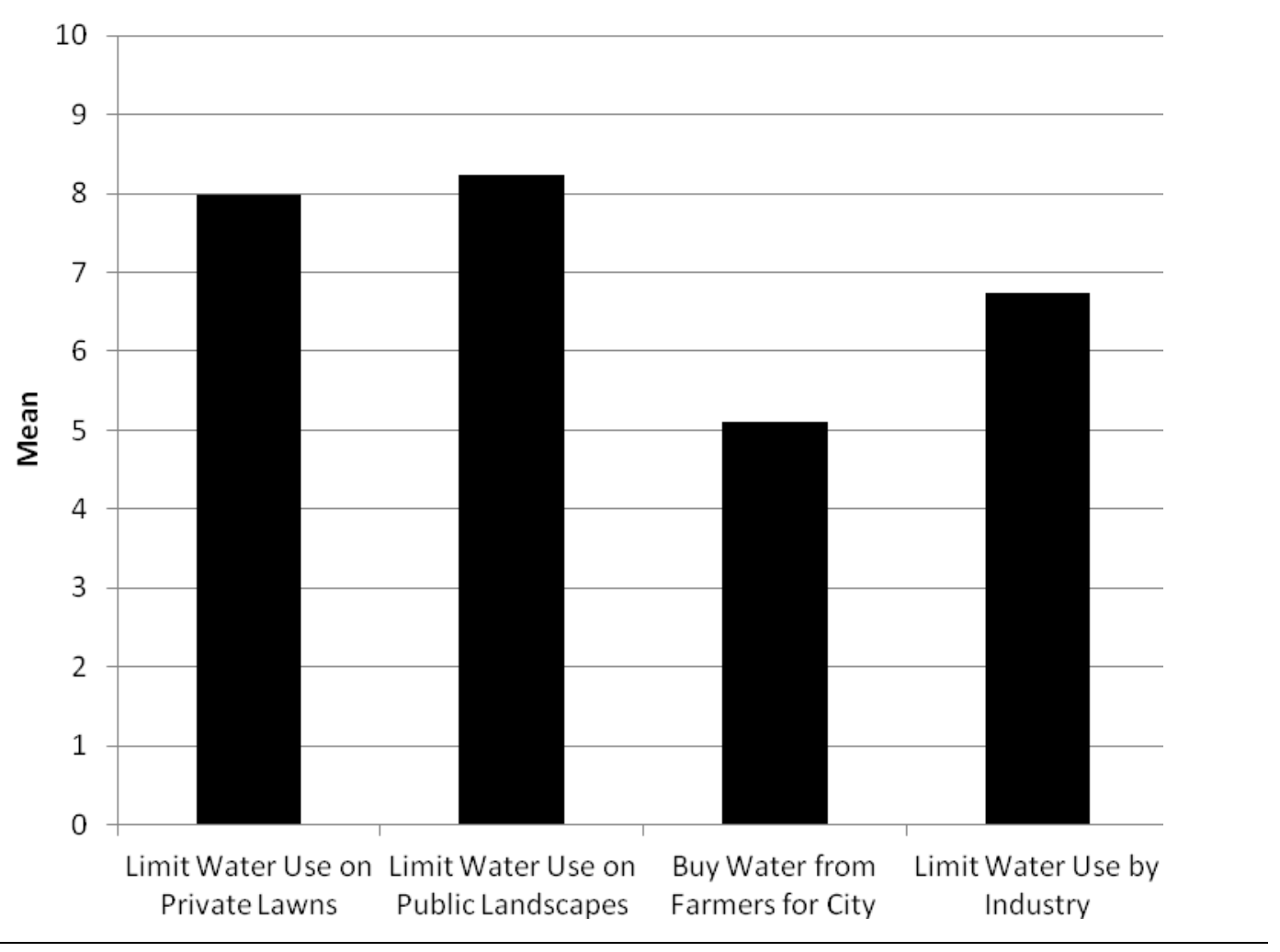


Figure 7: Favorability of Future Drought Strategies by Cities

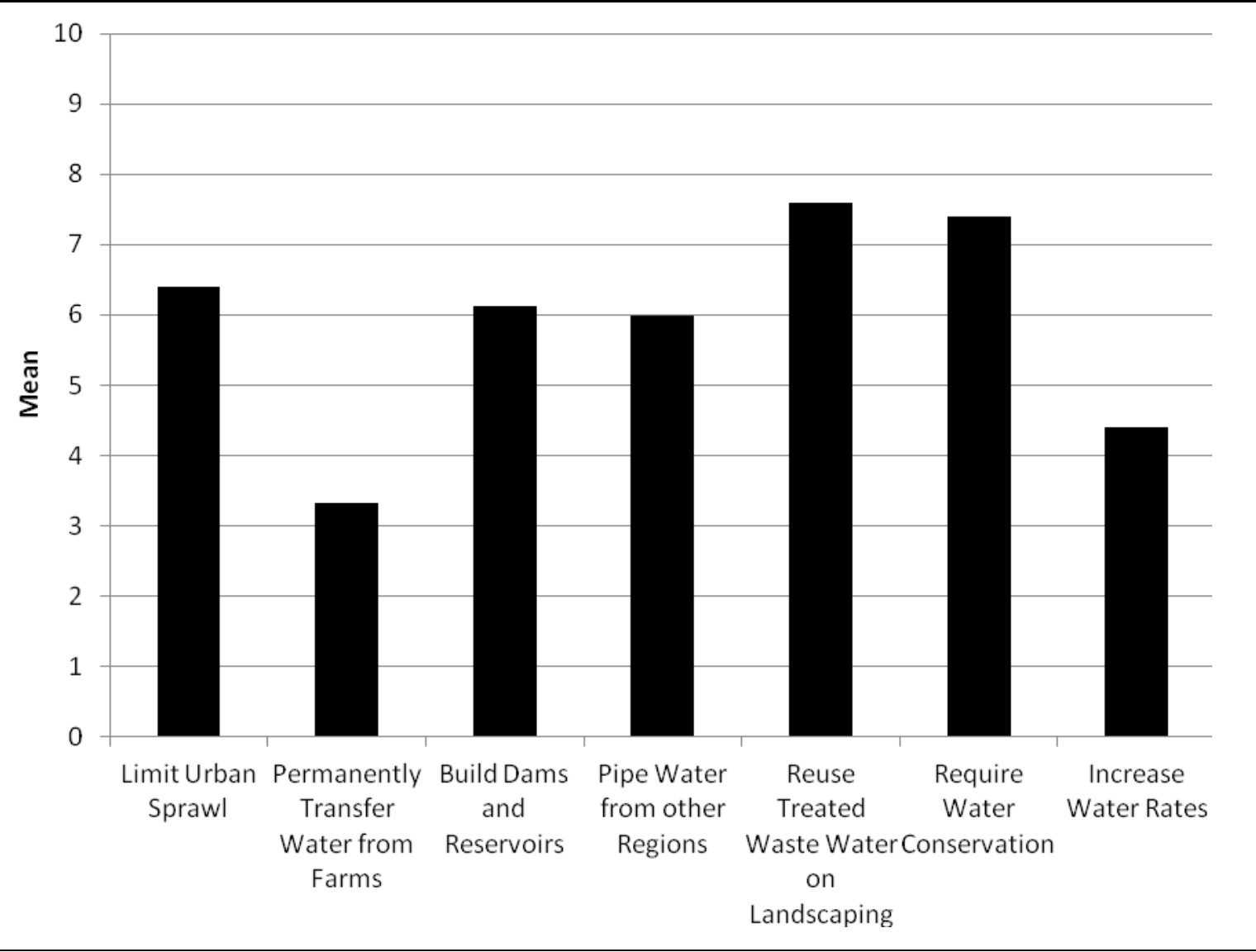


Table 4: Public Support for Water Policy Proposals

\begin{tabular}{|c|c|c|c|c|c|c|}
\hline & Strongly Oppose & Oppose & Unsure & Support & Strongly Support & Mean \\
\hline $\begin{array}{l}\text { Build infrastructure (dams, reservoirs, pipelines) to support } \\
\text { water demands during a drought }\end{array}$ & 1.54 & 5.48 & 34.67 & 45.05 & 13.25 & 2.62 \\
\hline Conduct campaigns for voluntary water conservation & 1.70 & 3.36 & 30.71 & 49.33 & 14.90 & 2.72 \\
\hline Require mandatory water conservation & 4.31 & 13.92 & 39.36 & 32.99 & 9.41 & 2.29 \\
\hline $\begin{array}{l}\text { Give tax incentives for the installation of water-saving } \\
\text { equipment }\end{array}$ & 1.78 & 4.46 & 25.71 & 49.80 & 18.25 & 2.78 \\
\hline $\begin{array}{l}\text { Develop a comprehensive national plan for allocating water } \\
\text { across state borders }\end{array}$ & 5.89 & 9.45 & 45.65 & 30.28 & 8.74 & 2.26 \\
\hline $\begin{array}{l}\text { Provide state tax cuts to companies that reduce their water } \\
\text { use }\end{array}$ & 2.76 & 6.55 & 32.12 & 47.87 & 10.69 & 2.57 \\
\hline Require low water use landscaping & 2.14 & 6.61 & 26.48 & 47.19 & 17.58 & 2.71 \\
\hline $\begin{array}{l}\text { Protect some water resources to preserve vildlife and } \\
\text { fishery habitats }\end{array}$ & .83 & 2.57 & 23.10 & 51.54 & 21.96 & 2.91 \\
\hline $\begin{array}{l}\text { Require that lawn watering use reclaimed/reused water } \\
\text { instead of drinking water }\end{array}$ & 1.86 & 4.62 & 28.07 & 42.91 & 22.54 & 2.79 \\
\hline
\end{tabular}

Values are percentages, except the mean. The mean is calculated using a coding scheme from 0 (strongly oppose) to 4 (strongly support). 
Appendix Table 1: Descriptive Statistics

\begin{tabular}{|c|c|c|c|}
\hline & Survey 1 & Survey 2 & Combined \\
\hline \multicolumn{4}{|l|}{ Gender } \\
\hline Male & 50.34 & 47.83 & 49.09 \\
\hline Female & 49.66 & 52.17 & 50.91 \\
\hline \multicolumn{4}{|l|}{ Education } \\
\hline Less than High School & 7.77 & 9.38 & 8.57 \\
\hline High School & 29.70 & 28.76 & 29.23 \\
\hline Some College & 30.31 & 29.44 & 29.88 \\
\hline Bachelor's Degree or Higher & 32.22 & 32.42 & 32.32 \\
\hline \multicolumn{4}{|l|}{ Race } \\
\hline White & 76.77 & 75.97 & 76.37 \\
\hline Black & 6.70 & 8.31 & 7.51 \\
\hline Hispanic & 10.59 & 10.37 & 10.48 \\
\hline Multiracial & 3.35 & 3.05 & 3.20 \\
\hline Other & 2.59 & 2.29 & 2.44 \\
\hline \multicolumn{4}{|l|}{ Age } \\
\hline $18-24$ & 9.60 & 7.86 & 8.73 \\
\hline $25-34$ & 14.17 & 14.87 & 14.52 \\
\hline $35-44$ & 14.93 & 14.65 & 14.79 \\
\hline $45-54$ & 18.51 & 17.24 & 17.87 \\
\hline $55-64$ & 20.56 & 22.43 & 21.49 \\
\hline $65-74$ & 15.84 & 16.02 & 15.93 \\
\hline $75+$ & 6.40 & 6.94 & 6.67 \\
\hline \multicolumn{4}{|l|}{ Income } \\
\hline Less than $\$ 15,000$ & 8.39 & 8.63 & 8.51 \\
\hline$\$ 15,000-\$ 29,999$ & 12.03 & 13.80 & 12.92 \\
\hline$\$ 30,000-\$ 49,999$ & 18.74 & 18.76 & 18.75 \\
\hline$\$ 50,000-\$ 74,999$ & 18.74 & 19.99 & 19.36 \\
\hline$\$ 75,000-\$ 99,999$ & 15.00 & 14.80 & 14.9 \\
\hline$\$ 100,000-\$ 149,999$ & 18.51 & 16.48 & 17.49 \\
\hline More than $\$ 150,000$ & 8.61 & 7.55 & 8.08 \\
\hline \multicolumn{4}{|l|}{ Party Identification } \\
\hline Democrat & 34.35 & 36.08 & 35.21 \\
\hline Republican & 30.39 & 28.07 & 29.23 \\
\hline Independent & 31.30 & 32.34 & 31.82 \\
\hline Number of Observations & 1,313 & 1,311 & 2,624 \\
\hline
\end{tabular}




\section{Appendix Table 2: Variable Definitions}

\begin{tabular}{|c|c|c|}
\hline & Question Wording & $n$ \\
\hline \multicolumn{3}{|l|}{ Figure 1} \\
\hline Battery Prompt & $\begin{array}{l}\text { "On a scale from } 0 \text { to } 10 \text {, with } 0 \text { indicating not at all concerned and } 10 \text { indicating extremely concerned, } \\
\text { how concerned are you about each of the following issues?" }\end{array}$ & \\
\hline Jobs \& Economic Growth & "Jobs and economic growth" & 2604 \\
\hline Immigration & "Immigration" & 2589 \\
\hline Pollution & "Pollution" & 2600 \\
\hline $\begin{array}{l}\text { Government Spending \& } \\
\text { National Debt }\end{array}$ & "Government spending/national debt" & 2605 \\
\hline $\begin{array}{l}\text { Global Warming \& } \\
\text { Climate Change }\end{array}$ & "Global warming and climate change" & 2606 \\
\hline Energy Supply & "Energy supply" & 2599 \\
\hline Health Care & "Health care" & 2598 \\
\hline $\begin{array}{l}\text { Terrorism \& National } \\
\text { Security }\end{array}$ & "Terrorism and national security" & 2603 \\
\hline The Environment & "The environment" & 2583 \\
\hline $\begin{array}{l}\text { Water Quality \& } \\
\text { Availability }\end{array}$ & "Water quality and availability" & 2601 \\
\hline \multicolumn{3}{|l|}{ Figure 2} \\
\hline $\begin{array}{l}\text { Public Education Battery } \\
\text { Prompt }\end{array}$ & $\begin{array}{l}\text { "Different levels of government claim responsibility for specific policy areas. Using the following } 0 \text { to } \\
10 \text { scale with } 0 \text { being Not at all Responsible and } 10 \text { being Completely Responsible please indicate } \\
\text { which group you believe should be responsible for managing public education policy." }\end{array}$ & \\
\hline Federal Government & "Federal Government" & 2579 \\
\hline State Government & "State Government" & 2579 \\
\hline Local Government & "Local Government" & 2584 \\
\hline Private Sector & "Private Sector" & 2579 \\
\hline $\begin{array}{l}\text { Homeland Security } \\
\text { Battery Prompt }\end{array}$ & $\begin{array}{l}\text { "Different levels of government claim responsibility for specific policy areas. Using the following } 0 \text { to } \\
10 \text { scale with } 0 \text { being Not at all Responsible and } 10 \text { being Completely Responsible please indicate } \\
\text { which group you believe should be responsible for managing homeland security policy." }\end{array}$ & \\
\hline Federal Government & "Federal Government" & 2555 \\
\hline State Government & "State Government" & 2537 \\
\hline Local Government & "Local Government" & 2540 \\
\hline Private Sector & "Private Sector" & 2541 \\
\hline Energy Battery Prompt & $\begin{array}{l}\text { "Different levels of government claim responsibility for specific policy areas. Using the following } 0 \text { to } \\
10 \text { scale with } 0 \text { being Not at all Responsible and } 10 \text { being Completely Responsible please indicate } \\
\text { which group you believe should be responsible for managing energy policy." }\end{array}$ & \\
\hline Federal Government & "Federal Government" & 2567 \\
\hline State Government & "State Government" & 2561 \\
\hline Local Government & "Local Government" & 2556 \\
\hline Private Sector & "Private Sector" & 2564 \\
\hline Water Battery Prompt & $\begin{array}{l}\text { "Different levels of government claim responsibility for specific policy areas. Using the following } 0 \text { to } \\
10 \text { scale with } 0 \text { being Not at all Responsible and } 10 \text { being Completely Responsible please indicate } \\
\text { which group you believe should be responsible for managing water policy." }\end{array}$ & \\
\hline Federal Government & "Federal Government" & 2571 \\
\hline State Government & "State Government" & 2577 \\
\hline Local Government & "Local Government" & 2577 \\
\hline Private Sector & "Private Sector" & 2573 \\
\hline \multicolumn{3}{|l|}{ Figure 3} \\
\hline Battery Prompt & $\begin{array}{l}\text { "On a scale from } 0 \text { to } 10 \text {, with } 0 \text { indicating Not at all Important and } 10 \text { indicating Extremely Important, } \\
\text { rate how important each of the following water uses is to you?" }\end{array}$ & \\
\hline Drinking & "Water for drinking" & 2588 \\
\hline Household Use & "Water for household use (e.g. showers, laundry, and toilets)" & 2586 \\
\hline Natural Environment & "Water for the natural environment such as fish and wildlife habitat" & 2579 \\
\hline Private Landscaping & "Water for landscaping homes and businesses" & 2586 \\
\hline Industrial Use & "Water for industrial use (e.g. manufacturing, mining and energy generation)" & 2588 \\
\hline Agriculture & "Water for agriculture (e.g., crops and livestock)" & 2579 \\
\hline Recreation & "Water for recreation (e.g., pools and boating)" & 2580 \\
\hline
\end{tabular}


Municipal Landscaping "Water for municipal landscaping (e.g., parks and golf courses)"

Table 1

Battery Prompt

Water to Meet Current

Needs

Water to Meet Future

Needs

Economy vs.

Environment

Fish/Wildlife vs.

Economy

Cities Divert from Rural

Areas

Conservation Affects Me

Voluntary Conservation

Conserve: Inconvenient

Conserve: Lower Water

Bill

Conserve: Environment

Conserve: Industrial Use

Conserve: Agriculture

Conserve: Drought Conditions

Figure 4

Most Important Water Issue

Table 2

Drought Frequency

Drought Severity

Table 3

Battery Prompt

Disruption of Water

Supply

Increased Food Prices

Increased Water Costs

Loss of Recreational

Activities

Damage to Animals \&

Plants

Reduced Water Quality

Increased Fires

Increased Water Use

Conflicts

Figure 5

Which Use Should be

Reduced First

Figure 6

Battery Prompt

Limit Use on Private

Lawns

Limit Use on Public

Lawns

Buy Water from Farmers
"Please indicate whether you Strongly Disagree, Disagree, Neither Disagree Nor Agree, Agree, or Strongly Agree with each of the following statements."

"There is enough water in my state to meet current needs." 2589

"There is enough water in my state to meet future needs."

2562

"In water planning, the economy is more important than the environment."

2572

"Water conservation for fish/wildlife habitat and economic growth are equally important."

2570

"Cities should be able to divert water from rural areas if they need more water."

2567

"The issues related to the conservation and availability of water do not affect me."

2560

"Household water restrictions should be voluntary rather than mandated by the government." 2557

"Making efforts to conserve water is inconvenient."

2568

"I am willing to conserve water to lower my water bill."

2576

"I am willing to conserve water to protect the environment."

2562

"I am willing to conserve water for industrial uses."

"I am willing to conserve water for agricultural uses."

2566

2563

"I am willing to conserve water under extreme drought conditions."

2575

"What do you think is the most important water related issue in your state?" 1) "Water Quality/Pollution;" 2) "Water Quantity/Drought in areas;" 3) "Water Distribution/Provide enough water 2578 to all users"

"Are droughts in your region becoming more common, less common, or continuing to occur at the same rate?"

"Are droughts in your region becoming more severe, less severe, or continuing to occur with the same severity?"

"How likely are the following drought impacts to occur in your region in the next five years?" Very Unlikely, Somewhat Unlikely, Unsure, Somewhat Likely, or Very Likely

"Disruption of Water Supply"

"Increased Food Prices"

2571

"Increased Water Costs" 2574

"Loss of Recreational Activities"

2577

"Damage to Animal and Plant Species"

2578

"Reduced Water Quality"

2572

"Increased Fires"

2575

"Increased Water Use Conflicts"

2580

"Which of the following water uses should be reduced first to lessen the impacts of drought?" 1) "City use," 2) "Agricultural use;" 3) "Industrial use;" or 4) "Individual use"

"During times when water availability is limited due to a short-term drought (lasting less than two years), a city may adopt several strategies to ensure it has enough water. Please rate the strategies that a city might consider on a scale of 0 to 10 with 0 being Not Favored by you and 10 being Highly Favored by you."

"Limiting water use on private lawns"

"Limiting water use on public landscapes"

"Buying water from farmers to use in cities" 


\begin{tabular}{|c|c|c|}
\hline $\begin{array}{l}\text { Limit Water Use by } \\
\text { Industry }\end{array}$ & "Limiting water use by industry" & 2579 \\
\hline \multicolumn{3}{|l|}{ Figure 7} \\
\hline Battery Prompt & $\begin{array}{l}\text { "Increasing population means that cities will need more water for the long run (more than ten years in } \\
\text { the future). Listed below are several possible strategies that a city might consider to ensure adequate } \\
\text { water supplies in the future. Please rate the strategies on a scale of } 0 \text { to } 10 \text { with } 0 \text { being Not Favored } \\
\text { by you and } 10 \text { being Highly Favored by you." }\end{array}$ & \\
\hline $\begin{array}{l}\text { Transfer Water from } \\
\text { Farms }\end{array}$ & "Permanently transferring water from farms to the city" & 2570 \\
\hline Build Dams \& Reservoirs & "Building dams and reservoirs" & 2565 \\
\hline Pipe Water & "Constructing pipelines to bring water from other regions" & 2567 \\
\hline $\begin{array}{l}\text { Reuse Treated Waste } \\
\text { Water }\end{array}$ & "Reusing treated waste water on lawns and landscapes" & 2567 \\
\hline Require Conservation & "Requiring water conservation" & 2565 \\
\hline Limit Urban Sprawl & "Limiting urban sprawl" & 2559 \\
\hline Increase Water Rates & "Increasing water rates" & 2564 \\
\hline \multicolumn{3}{|l|}{ Table 4} \\
\hline Battery Prompt & $\begin{array}{l}\text { "A number of policy options have been proposed to manage water resources. Please indicate } \\
\text { whether you Strongly Oppose, Oppose, Support, or Strongly Support each of the following options." } \\
\text { Respondents were also allowed to choose "Unsure." }\end{array}$ & \\
\hline Build Infrastructure & "Build infrastructure (dams, reservoirs, pipelines) to support water demands during a drought" & 2535 \\
\hline Voluntary Conservation & "Conduct campaigns for voluntary water conservation" & 2530 \\
\hline Require Conservation & "Require mandatory water conservation" & 2528 \\
\hline Tax Incentives & "Give tax incentives for the installation of water-saving equipment" & 2532 \\
\hline $\begin{array}{l}\text { Comprehensive National } \\
\text { Plan }\end{array}$ & "Develop a comprehensive national plan for allocating water across state borders" & 2530 \\
\hline State Tax Cuts & "Provide state tax cuts to companies that reduce their water use" & 2534 \\
\hline $\begin{array}{l}\text { Low Water Use } \\
\text { Landscaping }\end{array}$ & "Require low water use landscaping" & 2526 \\
\hline $\begin{array}{l}\text { Protect Wildlife \& Fish } \\
\text { Habitat }\end{array}$ & "Protect some water resources to preserve wildlife and fishery habitats" & 2532 \\
\hline $\begin{array}{l}\text { Reuse Treated Waste } \\
\text { Water }\end{array}$ & "Require that lawn watering use reclaimed/reused water instead of drinking water" & 2533 \\
\hline
\end{tabular}

